\title{
Acute Hepatitis-A Virus Infection as a Rare Cause of Hemophagocytic Lymphohistiocytosis
}

\author{
Ali Dogan, Sinan Demircioglu and Omer Ekinci \\ Department of Hematology, Faculty of Medicine, Yuzuncu Yil University, Van, Turkey
}

\begin{abstract}
Hemophagocytic lymphohistiocytosis (HLH) is a rare disorder of the mononuclear phagocytic system, characterised by histiocyte and lymphocyte activation. It can be classified as primary and secondary HLH. Primary HLH usually presents in childhood, and is associated with gene mutations. Secondary HLH usually presents in adulthood, and is due to an underlying infection, autoimmune disease or malignancy. We describe a case of HLH secondary to acute hepatitis-A virus infection, which was characterised by persistent fever, pancytopenia, splenomegaly, hyperferritinemia, and hemophagocytosis observed in the bone marrow.
\end{abstract}

Key Words: Hemophagocytic lymphohistiocytosis, Hepatitis-A, Mononuclear phagocytes.

How to cite this article: Dogan A, Demircioglu S, Ekinci O. Acute Hepatitis-A Virus Infection as a Rare Cause of Hemophagocytic Lymphohistiocytosis. J Coll Physicians Surg Pak 2021; 31(02):232-234.

\section{INTRODUCTION}

Hemophagocytic lymphohistiocytosis (HLH) is a rare disorder of the mononuclear phagocytic system, characterised by histiocyte and lymphocyte activation. ${ }^{1}$ It is characterised by high fever, maculopapular rash, abnormal liver functions, pancytopenia, hyperferritinemia, and coagulopathy. It can be classified as primary and secondary $\mathrm{HLH}^{2}$ Primary HLH usually presents in childhood and is associated with gene mutations. Secondary HLH usually presents in adulthood and is due to an underlying infection, autoimmune disease or malignancy. ${ }^{3}$ Among the infections triggering $\mathrm{HLH}$, viral infections are prevalent, with Epstein-Barr virus (EBV), cytomegalovirus (CMV), and human immunodeficiency virus (HIV) being the most common; whereas, HLH associated with hepatitis-A virus infection is only rarely encountered. ${ }^{4}$

We describe a case with virus-associated HLH secondary to acute hepatitis-A virus infection, which was characterised by persistent fever, pancytopenia, splenomegaly, hyperferritinemia and hemophagocytosis observed in the bone marrow.

Correspondence to: Dr. Ali Doğan, Department of Hematology, Faculty of Medicine, Yuzuncu Yil University, Van, Turkey

E-mail:dr.alidogan44@gmail.com

Received: August 07, 2019; Revised: November 20, 2019;

Accepted: December 09, 2019

DOI: https://doi.org/10.29271/jcpsp.2021.02.232

\section{CASE REPORT}

A 50-year male was admitted to our hospital with nausea, vomiting, fever, and weakness. The physical examination revealed fever and spleen was palpable $1 \mathrm{~cm}$ below the left costalmargin. Therewere nobleeding or encephalopathysymptoms and on examination, no rash or lymphadenopathy were noted. The systemic examination was normal. The laboratory investigations were as follows: haemoglobin $10.4 \mathrm{~g} / \mathrm{dL}$, leukocyte count $1400 / \mu \mathrm{L}$, neutrophil count $900 / \mu \mathrm{L}$, platelet count $14000 / \mu \mathrm{L}$, ferritin $1500 \mathrm{ng} / \mathrm{ml}$, triglycerides $386 \mathrm{mg} / \mathrm{dL}$, international normalised ration (INR) 1.1, fibrinogen $267 \mathrm{mg} / \mathrm{dl}$, creatinine $0.54 \mathrm{mg} / \mathrm{dL}$, serum aspartate aminotransferase (AST) $2680 \mathrm{u} / \mathrm{L}$, serum alanine aminotransferase (ALT) $702 \mathrm{u} / \mathrm{L}$, gamma-glutamyl transferase (GGT) 667 u/L, alkaline phosphatase (ALP) $321 \mathrm{u} / \mathrm{L}$, lactate dehydrogenase (LDH) $2000 \mathrm{u} / \mathrm{L}$, indirect bilirubin $0.5 \mathrm{mg} / \mathrm{dl}$, direct bilirubin $1.2 \mathrm{mg} / \mathrm{dL}$, and C-reactive protein (CRP) $18 \mathrm{mg} / \mathrm{L}$. ELISA test was positive for anti-hepatitis-A virus immunoglobulin M (anti-HAV IgM), while the other viral hepatitis tests were negative. Furthermore, normochromic, microcytic erythrocytes, leukopenia, and thrombocytopenia were found in the peripheral blood smear. Hemophagocytosis was observed in the bone marrow aspiration smear (Figure 1), and abdominal ultrasonography revealed splenomegaly. The patient was diagnosed with secondary HLH due to acute hepatitis-A virus infection, and treatment with intravenous immunoglobulin (IVIG) $(0.5 \mathrm{~g} / \mathrm{kg}$, for a period of 2 days) and dexamethasone $\left(10 \mathrm{mg} / \mathrm{m}^{2} /\right.$ day $)$ was initiated. On the $14^{\text {th }}$ day of treatment, hemoglobin level, leukocyte count, platelet count, and liver functions all improved, as well as, his symptoms; at which point, dexamethasone was gradually discontinued. During follow-up, anti-HAV IgM tested negative, while anti-HAV IgG tested positive. 


\section{DISCUSSION}

HLH is usually caused by dysfunction of the mononuclear phagocytic system, which causes uncontrolled immune damage, and it can be a potentially fatal condition. ${ }^{5}$ Secondary $\mathrm{HLH}$ is triggered by such factors as underlying malignancy, immunodeficiency, infection, or autoimmune disease. In a retrospective study of 62 adult HLH patients at the Mayo Clinic, the causes of $\mathrm{HLH}$ were identified as follows: malignancies $(52 \%)$, infections (34\%), autoimmune disorders ( $8 \%)$, and idiopathic causes $(6 \%)$. The most common malignancy observed was T-cell lymphoma ( $59 \%)$, while the most frequent cause of infection was the EBV (26\%). Other infectious agents leading to HLH were histoplasma capsulatum, CMV, blastomyces dermatitidis, mycobacterium kansasii, pseudomonas aeruginosa, and vancomycin-resistantenterococcus. ${ }^{6}$

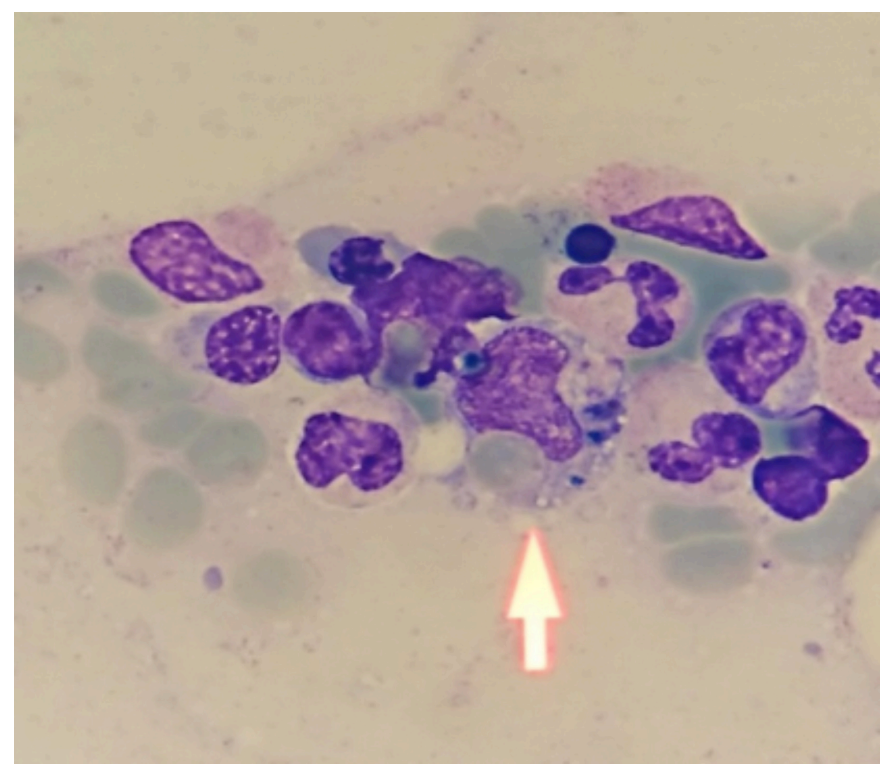

Figure 1: Bone marrow aspirate showing hemophagocytosis by histiocytes (arrow).

Riviere et al., found that the disease was most frequently triggered by malignancy $(60 \%)$, followed by infection $(25 \%)$, and autoimmune disorders (3\%) in their study of 162 adult HLH patients. Mycobacterium tuberculosis was the most commonly encountered infectious agent triggering $\mathrm{HLH}$, while the most prevalent viral agent was CMV. ${ }^{7}$

Secondary HLH is associated with infections, in particular, viral infections. Among the viruses commonly associated with secondary $\mathrm{HLH}$, whether alone or in combination, are the EBV, CMV, parvovirus, herpes simplex virus, varicella-zoster virus, measles virus, human herpes virus 8 (HHV-8), H1N1 influenza virus, parecho virus, and HIV. ${ }^{8}$

Hepatitis-A virus very rarely causes $\mathrm{HLH}$. In the literature, there are few cases of adult HLH due to hepatitis-A virus infection. ${ }^{9-11}$ We diagnosed our patient with HLH upon observing pancytopenia, fever, splenomegaly, elevated ferritin and triglyceride levels, and hemophagocytosis by the macrophages in the bone marrow. Hepatitis-A virus infection was determined to have triggered this case of $\mathrm{HLH}$. The patient fully recovered following treatment with dexamethasone and IVIG.

Diagnosis of $\mathrm{HLH}$ is frequently delayed due to its rare occurrence. Although triggering factors frequently include infectious agents, hepatitis-A vrius is rarely encountered. In the light of this patient and the previous publications, in patients with laboratory findings consistent with the presence of hepatitis and associated HLH, the possibility of HAV should be considered. We think that our experience with this case may be of help in early diagnosis of secondary HLH to viral hepatitis-A in the future.

\section{CONFLICT OF INTEREST:}

The authors declared no conflict of interest.

\section{AUTHORS' CONTRIBUTION:}

$A D, O E$ : Contributed to the conception and design of the work (evaluation of the case, detailed history taking, investigation and reporting the investigations).

SD: Revised and critically analysed the content.

OE: Finally approved the version.

\section{REFERENCES}

1. Henter JI, Samuelsson-Horne A, Aricò M, Egeler RM, Elinder $G$, Filipovich $A H$, et al. Histocyte society. Treatment of hemophagocytic Iymphohistiocytosis with HLH-94 immunochemotherapy and bone marrow transplantation. Blood 2002; 100(7):2367-73. doi: 10.1182/blood2002-01-0172.

2. Larroche C. Hemophagocytic lymphohistiocytosis in adults: Diagnosis and treatment. Joint Bone Spine 2012; 79(4): 356-61. doi: 10.1016/j.jbspin.2011.10.015.

3. Janka GE. Lehmberg K. Hemophagocytic syndromes. Blood Rev 2014; 28(4): 135-42. doi: 10.1016/j.blre.2014.03.002.

4. Henter JI, Horne A, Aricó M, Egeler RM, Filipovich AH, Imashuku S, et al. HLH-2004: Diagnostic and therapeutic guidelines for hemophagocytic lymphohistiocytosis. Pediatr Blood Cancer 2007; 48(2): 124-31. doi: 10.1002/pbc.21039.

5. Verbsky JW, Grossman WJ. Hemophagocytic Iymphohistiocytosis: Diagnosis, pathophysiology, treatment, and future perspectives. Ann Med 2006; 38(1):20-31. doi: 10.1080/07853890500465189.

6. Parikh SA, Kapoor P, Letendre L, Kumar S, Wolanskyj AP. Prognostic factors and outcomes of adults with hemophagocytic lymphohistiocytosis. Mayo Clin Proc 2014; 89(4):484-92. doi: 10.1016/j.mayocp.2013.12.012.

7. Rivière S, Galicier L, Coppo P, Marzac C, Aumont C, Lambotte $\mathrm{O}$, et al. Reactive hemophagocytic syndrome in adults: A retrospective analysis of 162 patients. Am J Med 2014; 127(11):1118-25. doi: 10.1016/j.amjmed.2014. 04.034 .

8. Ramos-Casals M, Brito-Zerón P, López-Guillermo A, Khamashta MA, Bosch X. Adult haemophagocytic syndrome. Lancet 2014; 383(9927):1503-16. doi: 10.1016/S0140- 6736(13)61048-X.

9. Navamani K, Natarajan MM, Lionel AP, Kumar S. Hepatitis- 
A virus infection-associated hemophagocytic lymphohistiocytosis in two children. Indian J Hematol Blo 2014; 30(Suppl 1):239-42. doi: 10.1007/s12288014-0341-0.

10. Tuon FF, Gomes VS, Amato VS, Graf ME, Fonseca GHH, Lazari $C$, et al. Hemophagocytic syndrome associated with
hepatitis-A: Case report and literature review. Rev Inst Med Trop Sp 2008; 50(2):123-7. doi: 10.1590/s003646652008000200012.

11. Tai CM, Liu CJ, Yao W. Successful treatment of acute hepatitis-A associated hemophagocytic syndrome by intravenous immunoglobulin. J Formos Med Assoc 2005; 104(7):507-10. 